\title{
Cellular Localization of Thrombin Receptor mRNA in Rat Brain: Expression by Mesencephalic Dopaminergic Neurons and Codistribution with Prothrombin mRNA
}

\author{
Jonathan R. Weinstein,, ${ }^{1}$ Stephen J. Gold, ${ }^{2}$ Dennis D. Cunningham, ${ }^{1}$ and Christine M. Gall2,3 \\ 'Department of Microbiology and Molecular Genetics, ${ }^{2}$ Department of Psychobiology, and ${ }^{3}$ Department of Anatomy \\ and Neurobiology, University of California, Irvine, California 92717
}

Cell culture studies demonstrating that the serine protease thrombin can induce neuronal and glial process retraction, glial proliferation, and changes in gene expression suggest a role for thrombin in CNS development, plasticity, and response to injury. Most cellular responses to thrombin are mediated by proteolytic actlvation of the cloned thrombin receptor (TR), a member of the seven transmembrane domain, G-protein-coupled receptor superfamily. As a step toward understanding the role of thrombin and its receptor in the CNS, Northern blot, in situ hybridization, and immunohistochemical techniques were used to analyze the cellular localization of TR mRNA in weanling-age rat brain. TR mRNA was broadly distributed across the neuraxis, although expression was very focal and often anatomically limited within specific neural structures. The greatest hybridization was associated with individual neurons in neocortex, cingulate/retrosplenial cortex, and subiculum, subsets of nuclei in hypothalamus, thalamus, pretectum, and ventral mesencephalon, and discrete cell layers in the hippocampus, cerebellum, and olfactory bulb. Patterns of hybridization included neuronal, glial, and ependymal cells, although white matter was uniformly negative, as were most cerebrovascular endothelial cells. Expression of TR mRNA by astroglia and dopaminergic neurons was confirmed by colocalization with immunoreactivity for glial fibrillary acidic protein (GFAP) in hippocampus and tyrosine hydroxylase in the substantia nigra. Comparison between TR and prothrombin (thrombin's precursor) cRNA hybridization demonstrated distinct but overlapping brain distributions of these transcripts, most clearly evident in postnatally developing, laminated structures. These results suggest widespread utilization of, and multiple physiologic, and possibly pathophysiologic, functions for, the thrombin/TR cell signaling system in the CNS.

[Key words: thrombin receptor, prothrombin, CNS, sub-

\footnotetext{
Received Aug. 9, 1994; revised Oct. 10, 1994; accepted Oct. 21, 1994.

We thank S. R. Coughlin and P. J. Isackson for providing thrombin receptor and prothrombin cDNAs, respectively; J. C. Lauterborn and P. J. Vaughan for their critical reviews of the manuscript during preparation; F. M. Donovan, D. C. Guttridge, A. L. Lau, J. S. Wong, A. C. Chen, and Z. Sun for excellent technical assistance. This work was supported by NIA Grant AG00538 to D.D.C. and C.M.G.; J.R.W. was funded in part by NIH Training Grant 2 T32 AG00096-11.

Correspondence should be addressed to Christine M. Gall at the above address.

Copyright (1) 1995 Society for Neuroscience $0270-6474 / 95 / 152906-14 \$ 05.00 / 0$
}

stantia nigra, neuronal plasticity, gene expression, in situ hybridization, protease nexin-1]

Proteolytic enzymes and their inhibitors can influence neuronal and glial differentiation and plasticity as a result of their ability to alter intracellular biochemistry, regulate process outgrowth, and induce cell migration and proliferation (Monard, 1988). These processes may involve degradation of extracellular matrix components (Liotta et al., 1981; Monard, 1988), cleavage of adhesion proteins (Chuong, 1990), and interactions with specific cell surface receptors (Pittman et al., 1989). The expression of several proteases and their specific inhibitors in the CNS has been characterized in vivo (Reinhard et al., 1988; Dihanich et al., 1991; Koo et al., 1991; Sumi et al., 1992). These findings suggest a number of possible roles for both proteases and their inhibitors in neural development, including regulation of axonal growth, synapse formation, and dendritic remodeling (Seeds et al., 1990; Liu et al., 1994).

Thrombin, a key protease in the final stages of blood coagulation, is formed from its precursor, prothrombin, at sites of vascular injury. The active protease catalyzes multiple biological reactions critical in hemostasis, thrombosis, and inflammation, through proteolytic cleavage of a number of circulating coagulation factors and direct receptor-mediated cellular activation. Thrombin is a potent stimulator of platelet aggregation (Berndt and Phillips, 1981), it is chemotactic for macrophages (BarShavit et al., 1983), mitogenic for fibroblasts (Glenn et al., 1980), and induces a variety of responses from vascular endothelial cells including disruption of barrier function (Garcia et al., 1993) and alteration in gene expression (Daniel et al., 1986; Garcia et al., 1993).

Cell culture studies have suggested a number of potentially important roles for thrombin in the brain. Picomolar concentrations of thrombin cause retraction of processes by neurons (Gurwitz and Cunningham, 1988; Grand et al., 1989) and glia (Cavanaugh et al., 1990; Nelson and Simon, 1990), while slightly higher concentrations induce astroglial mitosis (Cavanaugh et al., 1990). Thrombin can induce expression of c-fos and c-jun mRNA in an astrocytoma cell line (Trejo et al., 1992) and the synthesis and secretion of nerve growth factor (Neveu et al., 1993) and endothelin-1 (Ehrenreich et al., 1993) from cultured glia. Recent studies indicate that thrombin can regulate the viability of cultured neurons and astrocytes (P. J. Vaughan, C. J. Pike, C. W. Cotman, and D. D. Cunningham, unpublished observations). A recent in vivo study demonstrated that thrombin infused into rat forebrain caused infiltration of inflammatory 
cells, proliferation of mesenchymal cells, induction of angiogenesis, and an increase in the number of reactive astrocytes (Nishino et al., 1993).

Many of thrombin's cell signaling activities appear to be mediated by the recently cloned thrombin receptor (TR) (Rasmussen et al., 1991; Vu et al., 1991a). Thrombin activates this seven-transmembrane domain, G-protein-coupled receptor by proteolytic cleavage at a specific recognition sequence in TR's extracellular, amino-terminus (Vu et al., 1991b). The cleavage unmasks a new amino terminus, which functions as a tethered peptide ligand (Vu et al., 1991a; Chen et al., 1994), binding to a site on the receptor's second extracellular loop (Gerszten et al., 1994). This binding triggers a signal transduction cascade, resulting in the activation of phospholipase $\mathrm{C}$ and protein kinase $\mathrm{C}$, as well as the inhibition of adenylyl cyclase (Hung et al., 1992). TR-activating peptides corresponding to the first five amino acids of the new amino terminus can mimic most, if not all, of thrombin's cell-signaling activities, including those on cultured neural cells (Jalink and Moolenaar, 1992; Suidan et al., 1992; Beecher et al., 1994; Grabham and Cunningham, in press). The importance of thrombin's effects on neural cells in culture is supported by two recent in vivo studies that have reported expression of TR mRNA in the mouse embryonic nervous system (Soifer et al., 1994) and rat brain (Niclou et al., 1994).

Additional evidence supporting a role for thrombin in the CNS comes from studies demonstrating endogenous brain expression of prothrombin, and the thrombin inhibitor, protease nexin-1 (PN-1). Prothrombin mRNA has been detected in developing rat brain (Dihanich et al., 1991), and both the mRNA and protein appear to be synthesized by cultured astroglial cells (Deschepper et al., 1991). PN-1, a potent and specific thrombin inhibitor (Baker et al., 1980; Scott et al., 1985), which can counteract thrombin's effects on neural cells in culture (Cavanaugh et al., 1990; Gurwitz and Cunningham, 1990), is expressed in the CNS (Wagner et al., 1993; Reinhard et al., 1994). PN-1 is particularly concentrated in the olfactory system (Reinhard et al., 1988), a region characterized by continual axonal outgrowth, and around cerebral blood vessels (Choi et al., 1990), where the inhibitor could protect neural tissue from extravasated thrombin.

A significant step toward evaluating the role of thrombin and its cellular receptor in the CNS would be to determine the pattern of expression of TR in brain and to identify cell types that synthesize it. Here, we describe the cellular localization of TR mRNA in the rat CNS by in situ hybridization and combined in situ hybridization/immunohistochemistry. In addition, we demonstrate that TR and prothrombin mRNAs are regionally codistributed in select neural structures of weanling-age rats.

\section{Materials and Methods}

Animal and tissue preparation. Twelve postnatal day 25 (P25) male Sprague-Dawley rats were anesthetized by intraperitoneal injection with sodium pentobarbital and killed by intracardial perfusion with isotonic saline followed by $4 \%$ paraformaldehyde in $0.1 \mathrm{M}$ phosphate buffer, $\mathrm{pH}$ 7.2 (para/PB). Brains were removed from the cranium, postfixed in the perfusate for $24 \mathrm{hr}$ at $4^{\circ} \mathrm{C}$, transferred for cryoprotection to $20 \%$ sucrose in para/PB for $24-48 \mathrm{hr}$, and then sectioned on a freezing microtome at a thickness of $25 \mu \mathrm{m}$ in the coronal, or for olfactory bulb, parasagittal, plane.

Preparation of $c R N A$ and random primed cDNA probes. A 637 base pair (bp) rat thrombin receptor (TR) cDNA fragment (nucleotides 5751212) and a 397 bp human preprothrombin cDNA pst I restriction fragment (nucleotides 1550-1947) were subcloned into pBluescript II (Stratagene), linearized, and used as templates for in vitro transcription. For in situ hybridization, the above templates were transcribed using T3 and T7 RNA polymerases (Stratagene) in the presence of ${ }^{35} \mathrm{~S}$ - or ${ }^{33} \mathrm{P}$-UTP

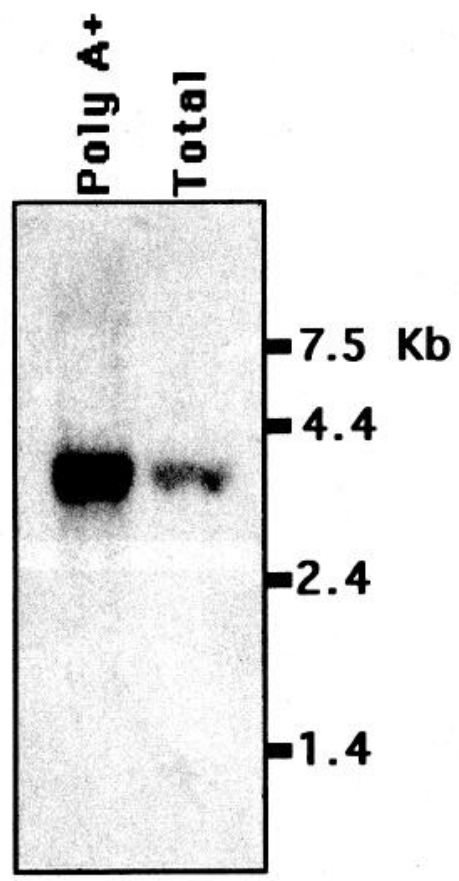

Figure 1. TR mRNA in weanling-age rat CNS. Film autoradiogram of a Northern blot hybridized with a random primed ${ }^{32} \mathrm{P}$-labeled TR cDNA probe. The two lanes shown contain 15 and $43 \mu \mathrm{g}$ of polyadenylated (Poly $A+$ ) and total RNA, respectively, isolated from P30 rat whole brain tissue. Numbers indicate the positions of RNA molecular weight standards (in $\mathrm{kb}$ ).

(DuPont-New England Nuclear) for generation of antisense and sense cRNA probes, respectively. For Northern blot analysis, the same TR fragment was random prime labeled using Klenow DNA Polymerase (Boehringer-Mannheim) and alpha ${ }^{32} \mathrm{P}-\mathrm{dATP}$ (Amersham).

In situ hybridization. Tissue sections were processed free-floating for in situ hybridization using procedures described in detail elsewhere (Lauterborn et al., 1991). Briefly, coronal tissue sections were permeabilized with proteinase $\mathrm{K}$, treated with acetic anhydride, and then hybridized with cRNA probes $\left(1 \times 10^{4} \mathrm{cpm} / \mu \mathrm{l}\right)$ at $60^{\circ} \mathrm{C}$ for $24-36 \mathrm{hr}$. Hybridization was followed by two rinses in $4 \times$ saline-sodium citrate (SSC), at $60^{\circ} \mathrm{C}$, treatment with ribonuclease A $(1.2 \mathrm{kU} / \mathrm{ml})(\mathrm{Sigma})$ for $30 \mathrm{~min}$ at $45^{\circ} \mathrm{C}$, and washes through descending concentrations of SSC to a final stringency of $0.1 \times \mathrm{SSC}$ at $60^{\circ} \mathrm{C}$. Dithiothreitol (DTT) was added to all washes at a final concentration of $5 \mathrm{~mm}$. Tissue was then mounted onto gelatin-coated slides and air dried. For emulsion autoradiography, slides were dehydrated in ethanol and defatted in chloroform. Hybridization was visualized by both film (Amersham $\beta$-max) and emulsion (Kodak NTB2) autoradiography with exposure times of 3 to $5 \mathrm{~d}$ and 28 to $42 \mathrm{~d}$, respectively. Following autoradiographic development, emulsion-coated slides were counterstained with either cresyl violet or toluidine blue, coverslipped with Permount, and analyzed by bright-field and dark-field microscopy.

Combined in situ hybridization/immunohistochemistry. For doublelabeling studies, tissue sections were first processed for in situ hybridization as described above. Sections were then rinsed in PB/DTT and incubated with either a 1:300 dilution of affinity purified rabbit polyclonal antisera against bovine adrenal tyrosine hydroxylase (Eugene Tech International) or a 1:400 dilution of affinity purified rabbit polyclonal antisera against bovine GFAP (Dako) in PB/DTT at $4^{\circ} \mathrm{C}$ for 16 hr. Sections were then processed for antibody localization using the Avidin/Biotin system with kit reagents (Vector Laboratories) and diaminobenzidine as chromogen. Following completion of the color reaction, tissue sections were mounted onto glass slides, air dried, defatted with chloroform, and processed for emulsion autoradiography as above.

Northern blot analysis. Total RNA was isolated from six P30 Sprague-Dawley rats using the acid guanidinium thiocyanate-phenolchloroform extraction procedure (Chomczynski and Sacchi, 1987). PolyA ${ }^{+}$RNA was selected by affinity chromatography using oligo-d(T)cellulose (Pharmacia). Both total and polyA ${ }^{+}$RNA were electropho- 

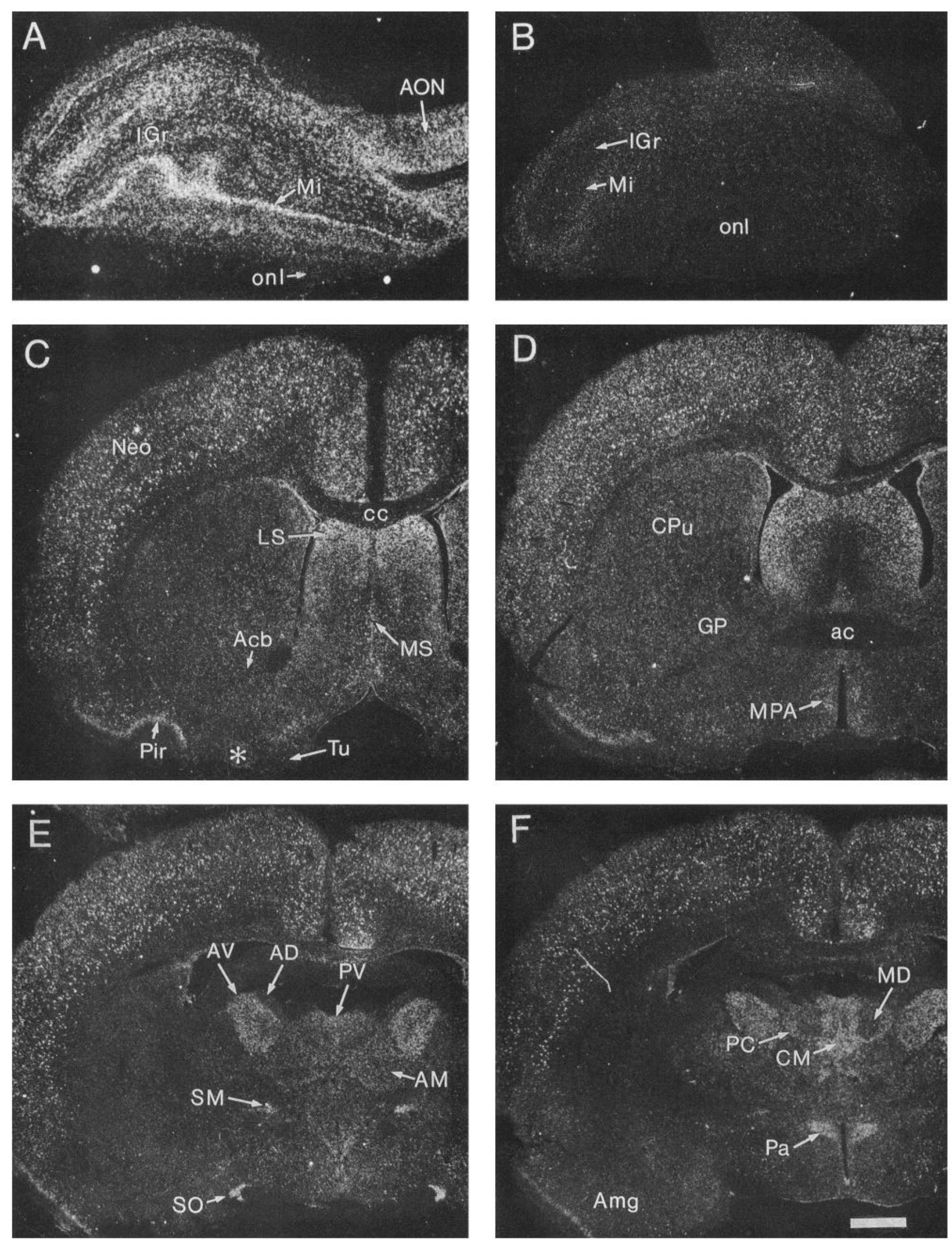

Figure 2. TR mRNA distribution in rostral forebrain of the P25 rat. Dark-field low-magnification photomicrographs showing in situ hybridization of TR antisense $(A, C-F)$ and sense $(B)$ radiolabeled cRNA probes in sagittal sections through olfactory bulb $(A$ and $B)$ and a rostral to caudal series of coronal tissue sections $(C-F)$ through telencephalon and diencephalon. Labeling is dense in the olfactory bulb $(A)$ mitral $(M i)$ and internal granule $(I G r)$ cell layers as well as more caudally in the anterior olfactory nucleus $(A O N)$. In contrast, no labeling is observed in a similar section 
resed in a $1.4 \%$ agarose gel containing $2.2 \mathrm{M}$ formaldehyde and $20 \mathrm{mM}$ HEPES, pH 7.8, and transferred overnight onto a nylon filter (DupontNew England Nuclear). The filter was then prehybridized in $50 \%$ formamide, $5 \times$ SSC, $50 \mathrm{~mm}$ Tris-HCl $\mathrm{pH} 7.5,0.1 \%$ sodium pyrophosphate, $1 \%$ sodium dodecyl sulfate (SDS), $0.2 \%$ polyvinylpyrrolidone $(\mathrm{MW}=40,000), 0.2 \%$ ficoll $(\mathrm{MW}=400,000)$, and $5 \mathrm{mM}$ EDTA at $42^{\circ} \mathrm{C}$ for $2 \mathrm{hr}$. Random primed ${ }^{32} \mathrm{P}$-labeled TR cDNA fragment was added $\left(6.8 \times 10^{7}\right.$ total $\left.\mathrm{cpm}\right)$ and hybridized at $42^{\circ} \mathrm{C}$ for $18 \mathrm{hr}$. The blot was washed twice at $42^{\circ} \mathrm{C}$ for 15 min with $2 \times$ SSC, $0.1 \%$ SDS and then once at $42^{\circ} \mathrm{C}$ for $5 \mathrm{~min}$ with $0.1 \times \mathrm{SSC}, 0.1 \%$ SDS. Autoradiography was performed at $-70^{\circ} \mathrm{C}$ plus one intensifying screen for $26 \mathrm{hr}$.

\section{Results}

\section{Regional distribution of thrombin receptor $(T R) M R N A$}

To determine the regional distribution of TR mRNA expression, tissue sections through rat brain and cervical spinal cord were processed for in situ hybridization using ${ }^{35} \mathrm{~S}$ - and ${ }^{33} \mathrm{P}$-labeled rat TR cRNAs synthesized from a 0.64 kilobase $(\mathrm{kb})$ cDNA template. The specificity of hybridization was examined at two levels. First, in Northern blot analysis, the cDNA template (used in the preparation of cRNA probes) hybridized intensely with a single $3.4 \mathrm{~kb}$ polyA ${ }^{+}$RNA transcript isolated from rat brain (Fig. 1). This result was consistent with the previously reported cloning of a $3.4 \mathrm{~kb}$ TR cDNA from rat aortic smooth muscle (Zhong et al., 1992) and the detection of a single $3.4 \mathrm{~kb}$ TR transcript in hamster (Rasmussen et al., 1991) and rat (Niclou et al., 1994) brain. Second, the ${ }^{35} \mathrm{~S}$-labeled TR sense riboprobe, produced only background levels of hybridization and no cellular labeling in brain tissue sections (Fig. $2 B$ ).

Autoradiographic label, indicating TR antisense cRNA hybridization, was broadly distributed across all levels of the rat CNS. The pattern and density of labeling varied widely from extremely dense and punctate in some gray matter arcas to background levels in others. Although the greatest hybridization was associated with neuronal nuclei and cell layers, some glial and ependymal cell populations were also labeled. No TR mRNA expression was detected in white matter. Weanling-age rats were chosen over older adult rats for this study after preliminary comparisons revealed similarly distributed but reduced levels of hybridization in the older animals (not shown). The regional distribution of TR cRNA hybridization from rostral to caudal levels of the neuraxis is described in the following paragraphs. Probes labeled with ${ }^{35} \mathrm{~S}$ and ${ }^{33} \mathrm{P}$ yielded equivalent patterns of hybridization; these results will be presented together.

\section{Telencephalon}

In sections through olfactory bulb, TR cRNA hybridization was greatest in the principal neuronal layers (Fig. 2A). Relatively intense hybridization labeled the mitral cell layer and, in an uneven fashion, the internal granule cell layer. The periglomerular region of the glomerular layer and the external plexiform layers were labeled at lower density. The olfactory nerve layer and central regions of the glomeruli were not labeled above background. More caudally, hybridization was diffusely distributed across the cellular layer of the anterior olfactory nucleus (Fig $2 A$ ), whereas the olfactory tubercle (Fig. 2C) and islands of Calleja (Fig. 2C) were not clearly labeled. In basal forebrain, moderate levels of hybridization were distributed across the lateral septum and labeled a few cells in the medial septum (Fig. $2 C$ ) and diagonal bands of Broca. Somewhat greater numbers of cells were labeled within the medial preoptic area (Fig. 2D). There was no clear hybridization associated with cells or distinct cytoarchitectonic fields of the nucleus accumbens (Fig. $2 C$ ), caudate/putamen (Fig. $2 D$ ), or globus pallidus (Fig. $2 D$ ), although the very diffuse autoradiographic label in these telencephalic regions was greater than background. In the amygdala (Fig. $2 F$ ), hybridization was low and diffusely distributed across the several subdivisions with labeling of a few individual cells evident only in the central and lateral nuclei.

In the neocortex, densely labeled cells were distributed across all neuronal layers with some variation in the number of labeled cells across cortical regions (Figs. $2 C-F, 3 A$ ). In tissue sections counterstained with toluidine blue, autoradiographic grains could be seen to label large neuronal perikarya (not shown). As in striatum, the cortical neuropil was characterized by diffuse labeling, which exceeded autoradiographic background, although the vast majority of neocortical cells were not clearly labeled. In the cingulate and retrosplenial cortices, densely labeled cells were scattered predominantly within the deeper layers (Fig. $3 B, D, E)$. In contrast, in piriform cortex, hybridization was greatest in a diffuse band overlying the densely packed neuronal layer II and labeled only a few scattered neurons in the deeper layers (Fig. 3C). In other allocortical regions (i.e., the entorhinal, perirhinal, and insular cortices) the cellular layers were associated with low levels of autoradiographic grains (Fig. $2 C-F$ ). Layer I of the piriform and entorhinal cortices was not labeled (Fig. 3C).

In hippocampus, there was a distinct laminar pattern of $T R$ cRNA hybridization with four features evident at all levels of the rostrocaudal axis. First, a relatively dense band of hybridization-labeled cells lining the hilar side of the granule cell layer (Fig. 4A-C). Under bright-field illumination, one could see this hybridization labeled small, Nissl-dark cells (Fig. 4C) with the characteristic appearance of immature neurons in this region of postnatal proliferative activity (Bayer, 1980). Considerably less hybridization was associated with the Nissl-pale neurons that comprise the more superficial, mature granule cell layer (Fig. $4 C$ ). Second, a diffuse band of autoradiographic grains labeled the pyramidal cell layer of CA1 and, at higher density, CA2 (Fig. 4A,B). Similar hybridization was not evident in region CA3 (Fig. $4 A, B$ ). Third, punctate clusters of grains were scattered across the molecular layers of both the dentate gyrus and the hippocampus proper. This was seen most clearly in strata radiatum and oriens of region CA1 (Fig. $4 A, B$ ). Under bright-field illumination, these clusters of grains within the molecular layers, and some of the hybridization within stratum pyramidale, were seen to be associated with small, darkly Nissl-stained cell bodies

hybridized with the sense TR probe $(B)$. In sections through basal forebrain ( $C$ and $D$ ), hybridization can be seen to label the piriform cortex (Pir), lateral septum $(L S)$, scattered cells in the medial septum $(M S)$, and the medial preoptic area $(M P A)$. Only diffuse hybridization is distributed across the nucleus accumbens $(A c b)$, globus pallidus $(G P)$, and caudate/putamen $(C P u)$, with no clear labeling in the olfactory tubercle $(T u)$ or islands of Calleja (asterisk in $C$ ). Densely labeled cells are distributed throughout neocortex (Neo in $C$ ). As seen in panels $E$ and $F$, in rostral diencephalon, relatively dense hybridization labels the anteroventral $(A V)$, centromedial $(C M)$, and paracentral $(P C)$ thalamic nuclei with lower density signal overlying the anteromedial $(A M)$ and paraventricular $(P V)$ nuclei. Several adjacent thalamic nuclei including the anterodorsal $(A D)$ and mediodorsal $(M D)$ nuclei were not labeled. Very dense hybridization labels the supraoptic ( $\mathrm{SO}$ ) and paraventricular $(\mathrm{Pa})$ nuclei of the hypothalamus, as well as the nucleus of the stria medullaris $(S M)$. Little hybridization was evident in the amygdala $(A m g)$. Areas of white matter including the corpus callosum ( $c c)$, anterior commissure $(a c)$, and the olfactory nerve layer (onl) were not labeled. Scale bar: $700 \mu \mathrm{m}$ for $A$ and $B, 1.00 \mathrm{~mm}$ for $C-F$ 

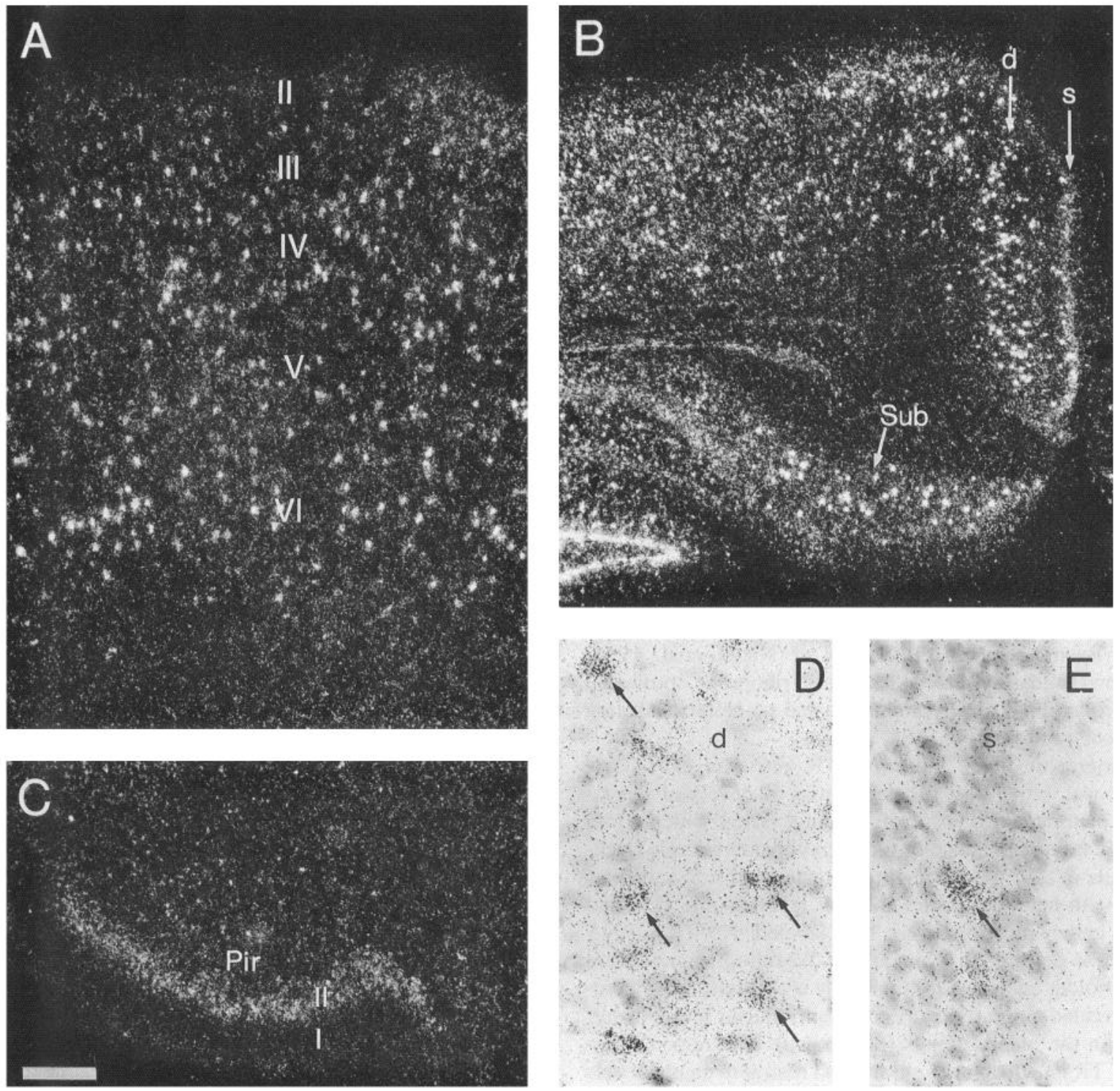

Figure 3. Distribution of TR mRNA in the P25 rat cortex. Dark-field, low-magnification $(A-C)$ and bright-field, high-magnification $(D$ and $E)$ photomicrographs showing in situ hybridization of the TR antisense ${ }^{35} \mathrm{~S}$-cRNA in tissue sections through neocortex $(A)$, retrosplenial cortex $(B$, $D$, and $E$ ) and piriform cortex $(C)$. In neocortex $(A)$, clusters of grains were scattered across layers II-VI. In retrosplenial cortex, diffuse hybridization was distributed across the superficial layer ( " $s$ " in $B$; seen at higher magnification in $E$ ), with a few well-labeled cells (black arrow in E). In the deeper layers (" $d$ " in $B$; seen at higher magnification in $D$ ) a greater number of densely labeled cells (black arrows in $D$ ) are evident. In $B$, very densely labeled neurons are also visible in the subiculum $(S u b)$. As shown in panel $C$, in piriform cortex (Pir) hybridization formed a relatively dense but diffuse band in layer II and labeled a few cells in the deeper layers; there was no hybridization in layer I $(C)$. Scale bar: $250 \mu \mathrm{m}$ for $A$, $400 \mu \mathrm{m}$ for $B$ and $C$, and $35 \mu \mathrm{m}$ for $D$ and $E$.

(not shown) with the characteristic appearance of glial cells in these preparations. However, the balance of hybridization within the pyramidal cell layer was associated with larger pale cells that appeared to be neurons. Finally, large neurons scattered within the deep aspect of the subicular cell layer were very densely labeled (Figs. $3 B, 4 B$ ). These subicular neurons were the most densely labeled cell group in the telencephalon.

\section{Diencephalon}

In dorsal thalamus, a distinct subset of nuclei were labeled by the TR cRNA. A diffuse, but relatively dense, distribution of autoradiographic grains labeled the anterior, intralaminar and, to a lesser extent, midline nuclear groups (Fig. 2E,F). In contrast, the ventral, lateral, and posterior nuclear groups were not labeled
(Figs. $2 E, F ; 5 A$ ). Within the anterior group, the anteroventral and anteromedial nuclei were more densely labeled, whereas hybridization was low in the adjacent anterodorsal nucleus (Fig. $2 E$ ). In the midline group, hybridization was greatest in the paraventricular (Fig. 2E), paratenial and interanterodorsal nuclei, and low in the rhomboid and reuniens nuclei. All four intralaminar nuclei (i.e., the parafascicular, centromedial, paracentral, and centrolateral) were labeled (Fig. $2 F$ ) and encircled the unlabeled mediodorsal nucleus (Fig. $2 F$ ). In caudal thalamus, the subparafascicular and ventral lateral geniculate nuclei were densely labeled (Fig. 5A). Hybridization extended into the intergeniculate leaflet but was not evident in the dorsal lateral geniculate (Fig. $5 A$ ) and medial geniculate nuclei (not shown). The lateral habenula was moderately well labeled. 

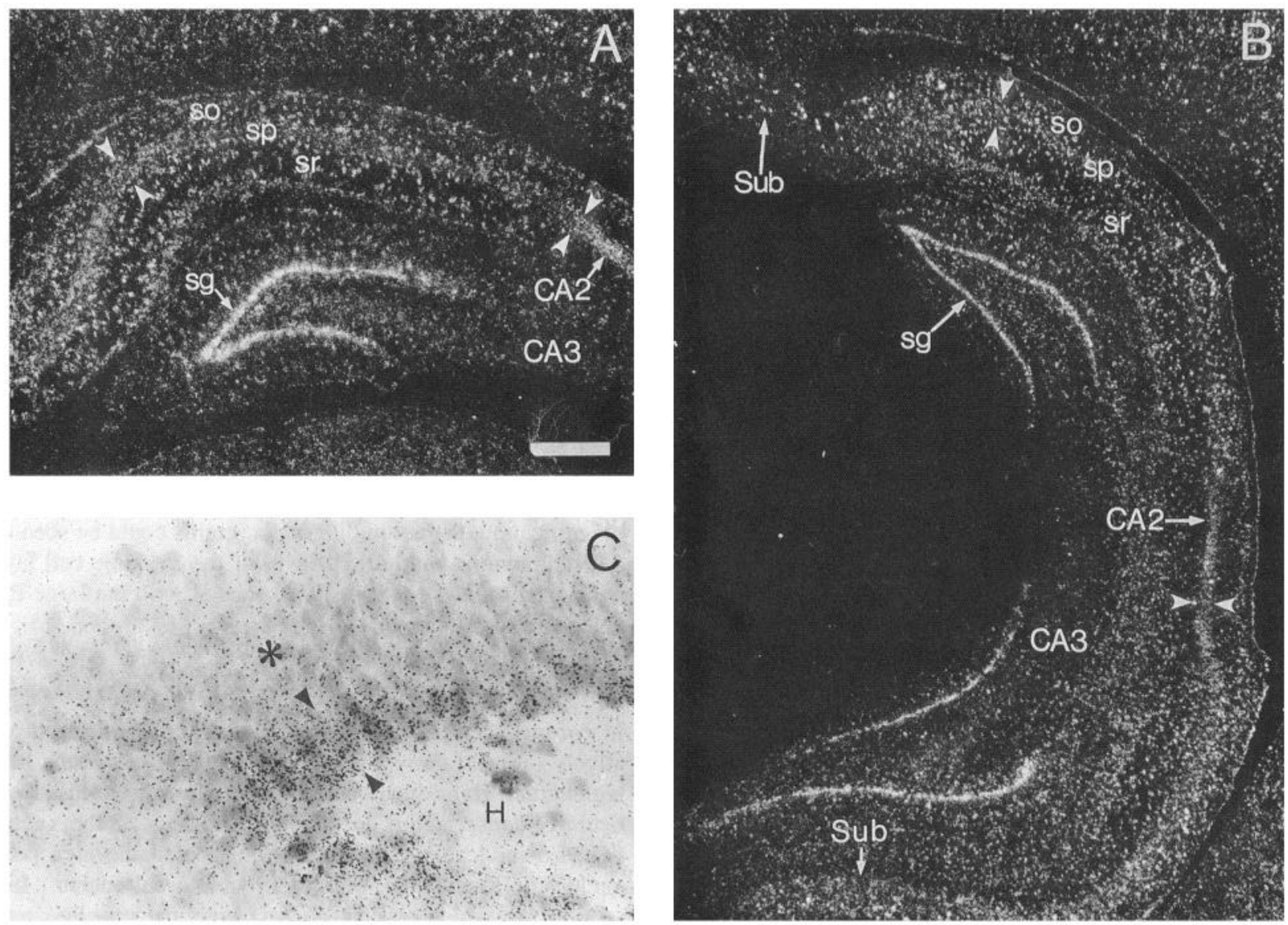

Figure 4. TR mRNA expression in the hippocampal formation. Dark-field, low-magnification $(A$ and $B)$ and bright-field, high-magnification $(C)$ photomicrographs showing in situ hybridization of the TR antisense ${ }^{35} \mathrm{~S}$-cRNA to tissue sections through rostral $(A$ and $C)$ and caudal $(B)$ hippocampal formation. A relatively dense band of hybridization is visible associated with stratum granulosum $(\mathrm{sg})$ throughout the rostrocaudal extent of the dentate gyrus $(A$ and $B)$. At high magnification $(C)$, one can see that this band is restricted to the Nissl-dark cells on the hilar side of the cell layer (black arrowheads), and does not overlie the Nissl-pale, mature granule (asterisk) and hilar $(H)$ neurons. Also, in $A$ and $B$, a diffuse autoradiographic label is visible in stratum pyramidale in CA1 and CA2 ( $s p$, white arrowheads denote boundaries) but not in CA3. Scattered clusters of autoradiographic grains label cells in strata radiatum (sr), oriens (so) and in the subiculum (Sub). Scale bar: $400 \mu \mathrm{m}$ for $A, 500 \mu \mathrm{m}$ for $B$, and $30 \mu \mathrm{m}$ for $C$.

In contrast to the dorsal thalamus, diffuse hybridization extended across most of the hypothalamus and preoptic area, with little respect for nuclear boundaries. In rostral sections, one could see regional elevations in the level of hybridization in the anteromedial preoptic and paraventricular (Fig. $2 F$ ) hypothalamic nuclei as well as in the medial preoptic area (Fig. 2D). In more caudal planes, there was a subtle gradient of decreasing hybridization radiating laterally away from the third ventricle (Fig. 2E). Thus, greater grain densities were associated with the ventromedial and arcuate nuclei than with the lateral hypothalamic area. The mammillary bodies (Fig. $5 B$ ) were labeled with a density comparable to medial fields in more rostral sections. In marked contrast, the supraoptic nucleus was very densely labeled (Fig. 2E). At higher magnification, hybridization was seen to be associated with virtually all of the large neurons in this nucleus.

\section{Mesencephalon}

In contrast to the diencephalon, hybridization was generally very low in the mesencephalon, with the striking exceptions of the accessory optic nuclei and the monoaminergic cell groups. High levels of hybridization in the pretectal area labeled the nucleus of the optic tract, olivary pretectal nucleus, dorsal terminal nucleus of the accessory optic tract, the pretectal nuclear complex, and the magnocellular nucleus of the posterior commissure (Fig. $5 B$ ). In these same coronal planes, there was extremely dense labeling in the ventral tegmental area, substantia nigra pars compacta and pars lateralis, as well as the peripeduncular nucleus (Fig. $5 B$ ). In contrast, the superior colliculus, red nucleus, and remaining central tegmentum were not labeled. The components of the raphe complex were labeled with increasing densities seen across the median, caudal linear, and dorsal nuclei (Fig. 5C). The interpeduncular nucleus, central gray, and retrorubral field neurons were labeled with relatively low densities of autoradiographic grains (not shown). In caudal mesencephalon, hybridization labeled the pontine nuclei and scattered cells in the central subdivisions of the inferior colliculus (Fig. $5 C$ ).

\section{Metencephalon}

TR cRNA hybridization was broadly distributed in the tegmentum, pons, and cerebellum. In the rostral pontine tegmentum, hybridization extended along the inferior border of the fourth ventricle encompassing the pontine central gray, dorsal raphe, dorsal tegmental, and parabrachial nuclei, as well as the locus 

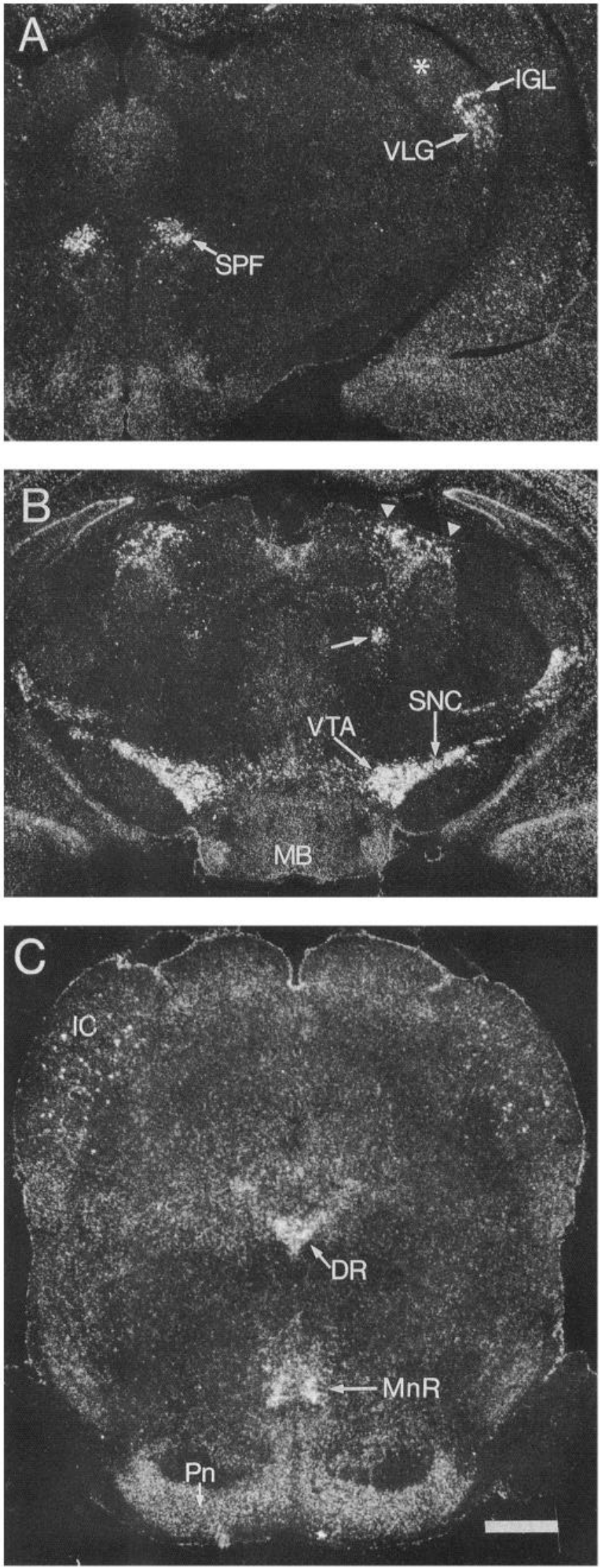

Figure 5. Distribution of TR mRNA in P25 rat brainstem. Dark-field, low-magnification photomicrographs showing the autoradiographic localization of TR cRNA hybridization in coronal tissue sections through coeruleus (Fig. 6A). There were low levels of hybridization in the central tegmentum including the cuneiform, subcoeruleus, and raphe pontis nuclei, and the pontine reticular formation (Fig. $6 A$ ). Neurons in the motor trigeminal nucleus were labeled with particularly high densities of autoradiographic grains (Fig. 6A). The principal sensory trigeminal, supra- and paragenual, vestibular and cochlear nuclei (Fig. 6A) were all well labeled. In contrast, there were low densities of autoradiographic grains in the facial, abducens, and spinal trigeminal nuclei (Fig. 6A). In caudal pons, a uniform, low density autoradiographic label spanned the reticular formation, and the raphe magnus, obscurus, and pallidus nuclei (not shown).

In cerebellum, neurons were labeled in the dentate nucleus, and a sharp band of hybridization clearly distinguished the Purkinje cell layer from the surrounding granule cell and molecular layers (Fig. 6A). The latter pattern was evident throughout the cerebellar cortex, including the floccular lobe (Fig. 6A). At high magnification, the autoradiographic grains could be seen to form a discontinuous band at the level of the Purkinje cell layer, but hybridization was not clearly associated with the large Purkinje cell bodies (not shown).

\section{Myelencephalon and spinal cord}

In coronal sections through the medulla, hybridization was relatively low and more narrowly distributed than in the pons and tegmentum. Hybridization surrounded the ventricle and was particularly dense in the dorsal motor nucleus of the vagus (Fig. $6 C$ ). Lower levels of hybridization labeled the area postrema, nucleus solitarius (Fig. 6C), and hypoglossal nucleus. In a few sections, in which aspects of the trigeminal ganglion remained attached, the ganglionic neurons were extremely heavily labeled (Fig. 6B). No clear hybridization was detected in medullary regions of the reticular formation or raphe nuclei (not shown). In cervical spinal cord, low levels of labeling were distributed within gray matter, most particularly surrounding the central canal, whereas the white matter was not labeled (not shown).

\section{Ependymal, meningeal, and vascular elements}

The ependymal ventricular lining was labeled throughout the brain. At high magnification (Fig. 7A) hybridization appeared to be associated with both the ependymal and subependymal layers of epithelial cells. Hybridization was also evident in other ependymal structures, including the subfornical organ (Fig. 7B) and choroid plexus (not shown). The pia matter was labeled, whereas the endothelial cells of the cerebrovasculature (e.g., capillaries and larger vessels) were generally not (Fig. $7 C$ ).

$\leftarrow$

caudal diencephalon $(A)$, the meso-diencephalic junction $(B)$, and metencephalon $(C)$. In $A$, dense hybridization labels neurons in the subparafascicular $(S P F)$ and ventral lateral geniculate $(V L G)$ nuclei as well as in the intergeniculate leaflet $(I G L)$. Note the absence of hybridization in the dorsal lateral geniculate nucleus (asterisk). In $B$, extremely dense hybridization is visible in several pretectal nuclei (arrowheads) and the magnocellular nucleus of the posterior commissure (arrow). Similarly high density label is evident in the substantia nigra pars compacta $(S N C)$ and ventral tegmental area (VTA), with lower density label in the mammillary bodies $(M B)$. In $C$, moderately dense hybridization labels the dorsal $(D R)$ and median $(M n R)$ raphe nuclei, pontine nuclei $(P n)$, and scattered cells in the inferior colliculus (IC). Scale bar: $800 \mu \mathrm{m}$ for $A$, $1.00 \mathrm{~mm}$ for $B$, and $600 \mu \mathrm{m}$ for $C$. 

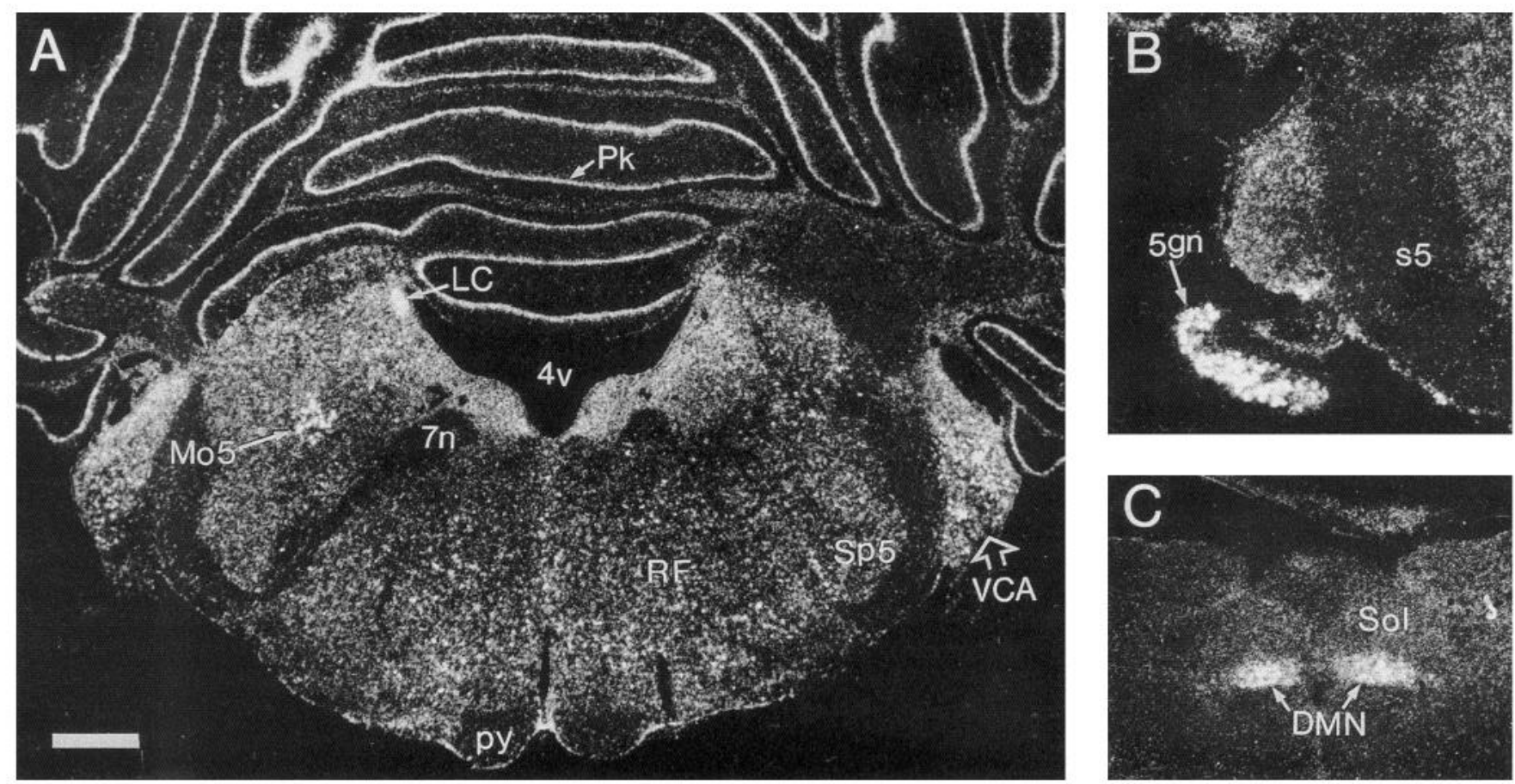

Figure 6. Broad distribution of TR cRNA hybridization in the cerebellum and caudal brainstem. Dark-field, low-magnification photomicrographs showing in situ hybridization of TR cRNA probes in coronal tissue sections through cerebellum and pontine tegmentum $(A)$, the trigeminal ganglion $(B)$, and myelencephalon $(C)$. Intense hybridization is visible in $A$, overlying the cerebellar Purkinje cell layer $(P k)$, tegmental, and vestibular nuclei along the floor of the fourth ventricle $(4 v)$, a cluster of neurons in the motor nucleus of the trigeminal nerve $(M o 5)$, the ventral cochlear nucleus $(V C A)$, and the locus coeruleus $(L C)$. Labeled cells are also visible in the reticular formation $(R F)$ and the spinal trigeminal nucleus $(S p 5)$. In $B$, dense hybridization labels the large, pseudounipolar neurons of the trigeminal ganglion (5gn). Note in both $A$ and $B$, the absence of hybridization in white matter, including the genu and root of the facial nerve $(7 n)$, the spinal trigeminal tract $(s 5)$, and the pyramidal tract $(P y)$. Dense hybridization is visible in $C$, labeling the dorsal motor nucleus of the vagus $(D M N)$ and with less intensity, the nucleus solitarius $(S o l)$. Scale bar: $650 \mu m$ for $A, 300 \mu \mathrm{m}$ for $B$, and $450 \mu \mathrm{m}$ for $C$.

\section{Localization of TR MRNA in dopaminergic neurons and astrocytes}

The pattern of densely labeled cells in the substantia nigra/ventral tegmental area corresponded closely with the well-documented distribution of dopaminergic neurons in this region. To establish TR mRNA expression by these neurons, cellular double labeling experiments were carried out using immunohistochemical staining for tyrosine hydroxylase, a marker for dopaminergic neurons, in combination with TR cRNA in situ hybridization. Virtually all cells containing the brown cytoplasmic stain indicating tyrosine hydroxylase immunoreactivity were clearly labeled with ${ }^{35} \mathrm{~S}$-TR cRNA (Fig. $8 A$ ). Moreover, nonimmunoreactive cells and neuropil in the region did not appear to be autoradiographically labeled (Fig. $8 A$ ).

In the molecular layers of the hippocampus, clusters of autoradiographic grains were associated with cells with the Nissl staining characteristics of astroglia. To determine if astrocytes express TR mRNA in this region, in situ hybridization of the TR cRNA was combined with immunostaining for GFAP. In strata radiata and oriens, the majority of GFAP-positive cells also expressed TR mRNA. Autoradiographic grains, indicative of TR cRNA hybridization, were observed directly overlying brown immunostained somata and processes (Fig. $8 B$ ). In other hippocampal laminae and in neocortex, only a small proportion of GFAP-positive cells were labeled, indicating that the incidence of detectable TR mRNA expression by astroglia varies across brain areas.

\section{Regional codistribution of TR and prothrombin mRNAs}

The widespread but discrete distribution of TR cRNA hybridization prompted us to examine select brain regions for codistribution with prothrombin mRNA. A previous study provided a regional CNS distribution of prothrombin mRNA expression, identifying signal in a number of embryonic and early postnatal rat brain structures including olfactory bulb, cortex, hippocampus, colliculi, striatum, thalamus, and substantia nigra (Dihanich et al., 1991). In the present study, weanling-age rat brain sections were processed for in situ hybridization with ${ }^{35} \mathrm{~S}$ - and ${ }^{33} \mathrm{P}$-labeled $0.4 \mathrm{~kb}$ prothrombin antisense cRNAs. Throughout most brain regions, the prothrombin cRNAs generated a moderately dense and diffuse pattern of hybridization that was greatest in association with neuronal cell layers and nuclei. Only background hybridization, equivalent to that seen with the sense probe, was evident in zones predominantly populated by glial cells such as layer I neocortex. Light and diffuse autoradiographic signal labeled white matter fiber tracts at slightly above background densities. In general, the regional distribution of hybridization was consistent with that reported by Dihanich et al. (1991).

The codistribution of prothrombin and TR mRNAs was evident in select brain regions, particularly in highly laminated structures. However, in these regions of coexpression, the two mRNAs exhibited overlapping but distinct laminar and cellular distributions. In the olfactory bulb, prothrombin cRNA hybridization was observed across all neuronal laminae (Fig. 9A), whereas only very low densities of autoradiographic grains la- 

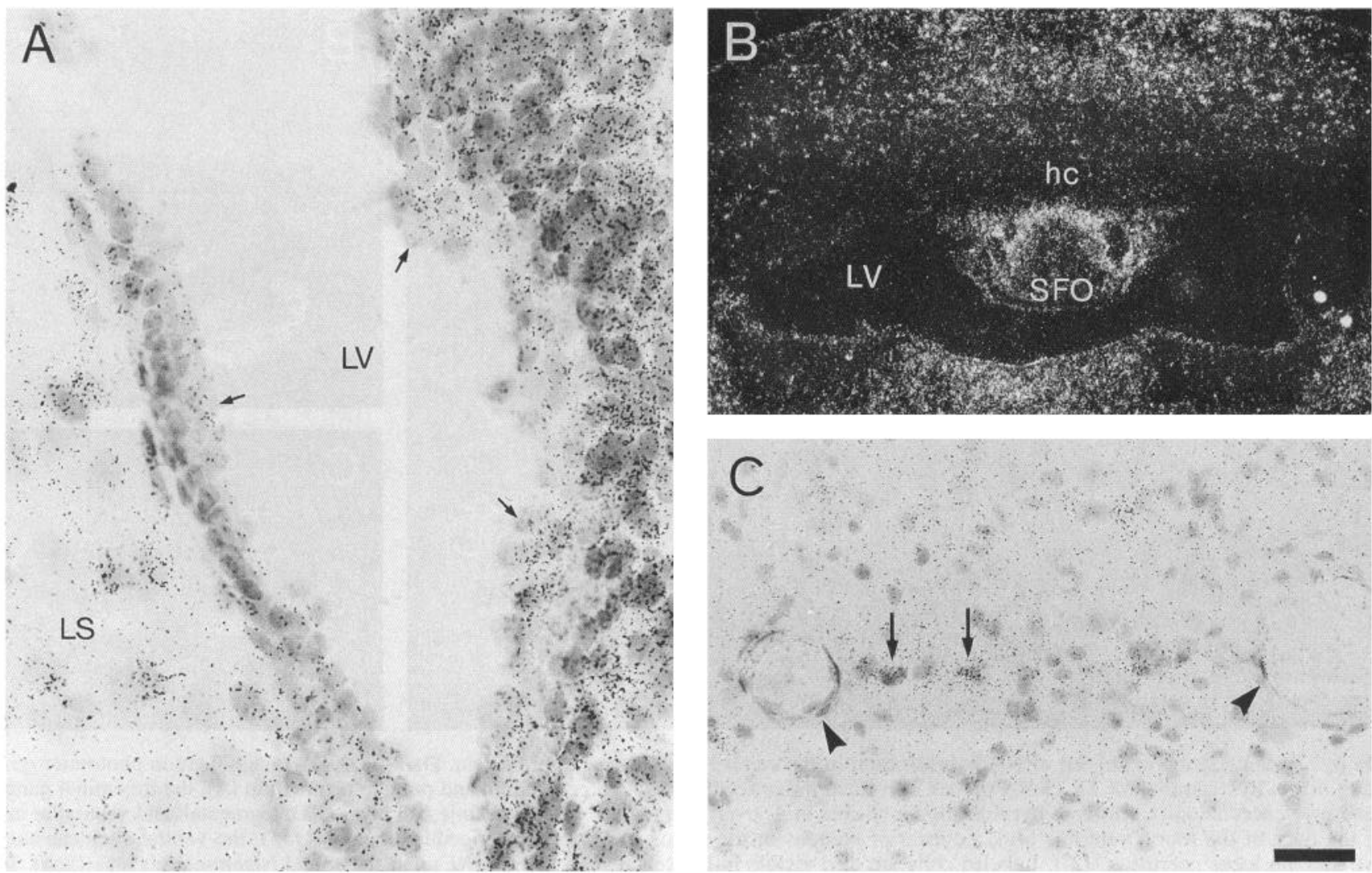

Figure 7. TR mRNA localization in ependymal cells but not cerebral vascular elements. Bright-field, high-magnification $(A$ and $C)$ and dark-field, low-magnification $(B)$ photomicrographs showing in situ hybridization of TR cRNA probes in coronal tissue sections through lateral ventricle $(A)$, subfornical organ $(B)$, and hippocampal fissure $(C)$. In $A$, ependymal (arrows) and subependymal (Nissl-dark) cells lining the lateral ventricle $(L V)$ are clearly labeled with autoradiographic grains as are nearby neurons in the lateral septum $(L S)$. In $B$, moderately dense hybridization is visible overlying the subfornical organ $(S F O)$, contrasting the lack of hybridization in the adjacent hippocampal commissure $(h c)$. In $C$, labeled glial cells (arrows) flank unlabeled cerebrovascular endothelial cells (arrowheads). Scale bar: $20 \mu \mathrm{m}$ for $A, 300 \mu \mathrm{m}$ for $B$, and $40 \mu \mathrm{m}$ for $C$.
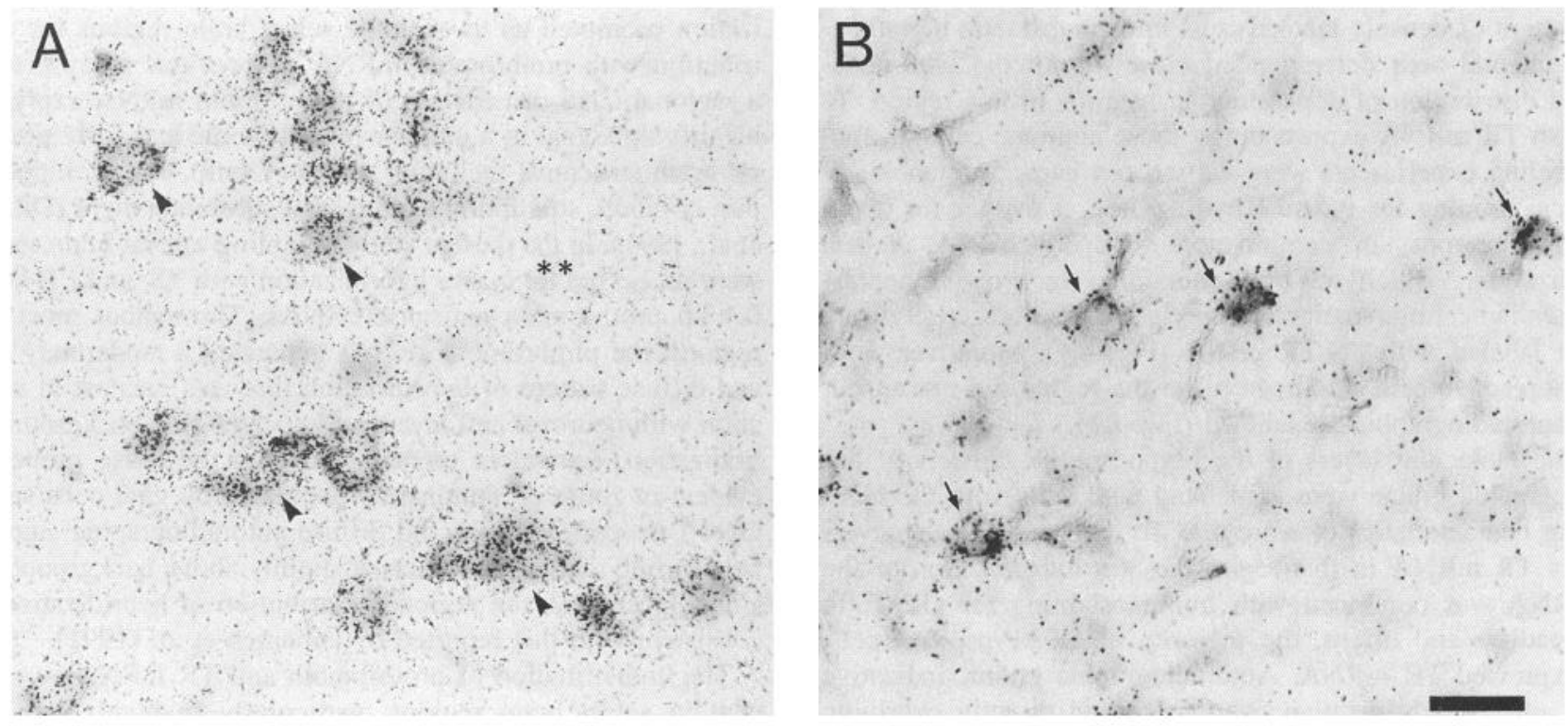

Figure 8. Localization of TR mRNA in dopaminergic neurons of the substantia nigra and hippocampal astrocytes. High-magnification, brightfield photomicrographs showing the colocalization of TR antisense ${ }^{35} \mathrm{~S}$-cRNA hybridization with tyrosine hydroxylase $(A)$ and glial fibrillary acidic protein (GFAP) (B) immunoreactivity. In $A$, the arrowheads indicate examples of double-labeled cells in the pars lateralis region of the substantia nigra. The surrounding neuropil and nonimmunoreactive cells (double asterisk) show only background hybridization. In $B$, arrows denote doublelabeled, process-bearing astrocytes in stratum radiatum of the hippocampus. Scale bar: $20 \mu \mathrm{m}$ for $A$ and $18 \mu \mathrm{m}$ for $B$. 

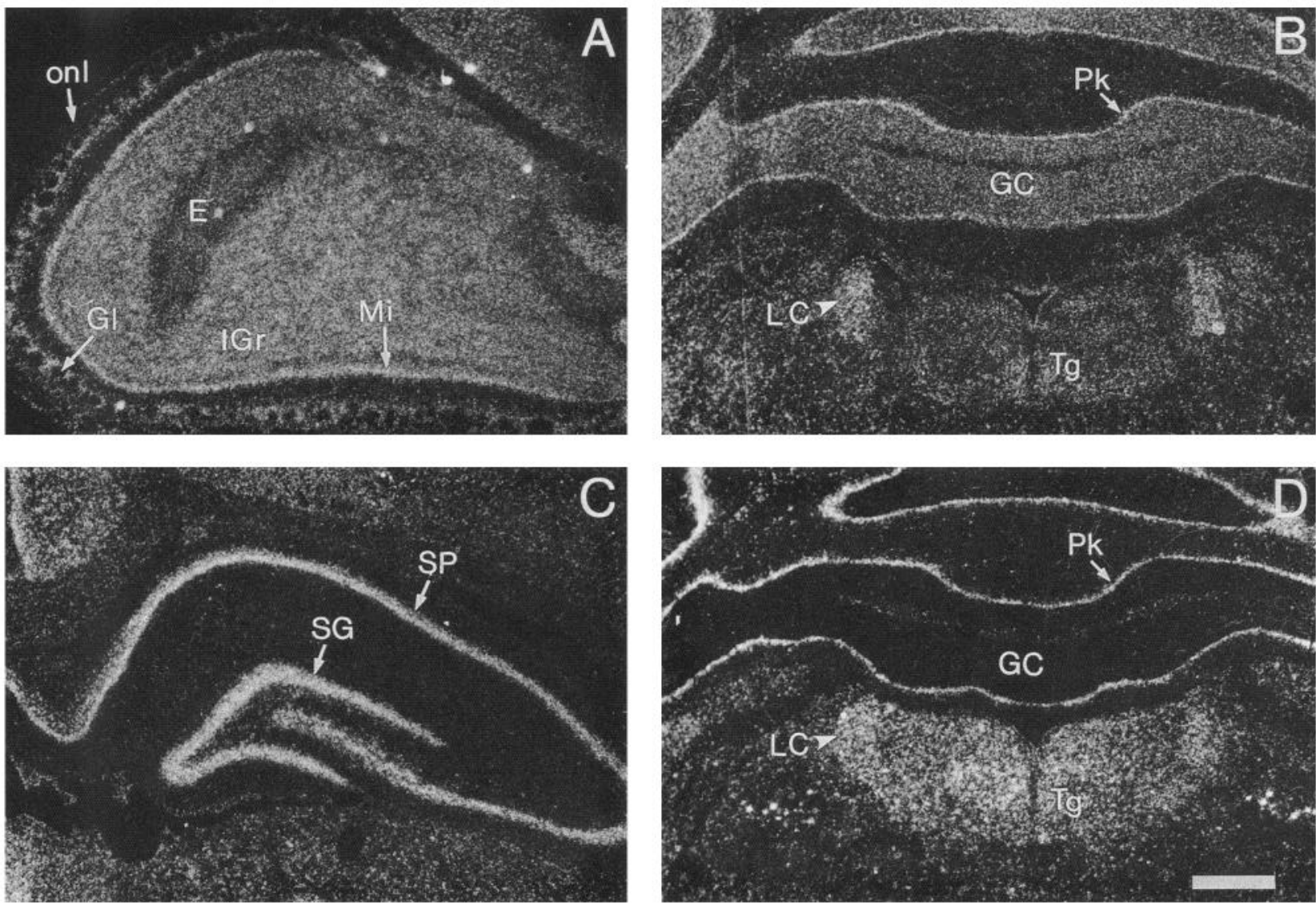

Figure 9. Overlapping, but distinct distributions of prothrombin and TR mRNAs in P25 rat brain. Dark-field, low-magnification photomicrographs showing in situ hybridization of antisense prothrombin $(A-C)$ and TR $(D){ }^{33}$ P-cRNA probes in a sagittal section through olfactory bulb $(A)$, and coronal sections through cerebellum/pontine tegmentum $(B$ and $D)$ and hippocampal formation $(C)$. In olfactory bulb $(A)$, prothrombin cRNA hybridization is distributed across the mitral $(\mathrm{Mi})$ and internal granule $(I G r)$ cell layers, and labels cells encircling the glomeruli $(G l)$. Very low levels of hybridization are evident in the olfactory nerve layer $(o n l)$ and ventricular ependyma $(E)$. In $(C)$, the prothrombin cRNA is seen to label the full depth of stratum granulosum $(S G)$ and stratum pyramidale $(S P)$ throughout CA1-CA3. (For comparison, TR mRNA distribution in olfactory bulb and hippocampal formation is shown in Figs. 2 and 4, respectively.) In $B$ and $D$, a direct comparison of prothrombin $(B)$ and TR (D) mRNA distribution in the cerebellum and pontine tegmentum is shown. Both transcripts are expressed in the cerebellar Purkinje cell layer $(P k)$ and in the locus coeruleus $(L C)$. The prothrombin cRNA $(B)$ labeled the granule cell layer $(G C)$ of the cerebellum, whereas TR cRNA $(D)$ did not. In contrast, TR cRNA hybridization is greater than that of prothrombin in the tegmental nuclei $(\mathrm{Tg})$. Scale bar: $600 \mu \mathrm{m}$ for $A, 500 \mu \mathrm{m}$ for $B$ and $D$, and 450 $\mu \mathrm{m}$ for $C$.

beled the olfactory nerve layer, the glomeruli, and the deep ependymal lining of the ventricles (Fig. 9A). The rather uniform distribution of prothrombin cRNA labeling in the olfactory bulb contrasted with the sharp variations in signal intensity seen with the TR cRNA (Fig. 2A). Nevertheless, the prothrombin and TR mRNAs were clearly codistributed in the mitral and granule cell layers. In neocortex, prothrombin cRNA hybridization spanned layers II through VI at moderately dense levels (not shown). Although both prothrombin and TR mRNAs were expressed in the same cortical lamina, the diffuse pattern of prothrombin cRNA hybridization differed considerably from the dispersed, intense clusters of signal seen with the TR riboprobe (Fig. 3A). In the hippocampal formation, prothrombin cRNA hybridization was evenly distributed across the depth of the granule cell layer (Fig. 9C) as well as throughout stratum pyramidale (Fig. 9C). As described above, in hippocampus, TR mRNA levels were greatest in a subpopulation of cells within the hilar aspect of the granule cell layer (Fig. $4 C$ ) and in scattered cells in the molecular layers (Fig. $4 A, B$ ). The preferential codistribution of the two transcripts was more striking in the cerebellum and select areas of the brainstem (Fig. 9B,D). Prothrombin cRNA hybridization was distributed across the cerebellar Purkinje and granule cell layers (Fig. 9B). In addition, the prothrombin cRNA labeled the locus coeruleus and, at lower levels, regions along the floor of the fourth ventricle (Fig. 9B). In contrast, TR cRNA labeling was more intense and anatomically limited in the cerebellum, clearly delineating only the Purkinje cell layer (Figs. 6A, 9D). In the pontine tegmentum, TR cRNA hybridization was more intense and widely distributed, although the TR and prothrombin mRNAs were both expressed in overlapping subsets of nuclei including the locus coeruleus and central gray (Fig. 9B,D).

\section{Discussion}

The present in situ hybridization results demonstrate that in young adult rat brain TR mRNA expression occurs in many different cell types, with wide variations in regional intensity. The density of autoradiographic label indicated that TR mRNA expression is greatest in select populations of neurons in cortex, mesencephalon, and brainstem, is more diffusely distributed in a subset of thalamic, hypothalamic, and brainstem nuclei, but is also present in fields enriched in glial and ependymal cells. Combined immunohistochemical/in situ hybridization studies lo- 
calized TR mRNA in mesencephalic dopaminergic neurons and hippocampal astrocytes. In addition, the results demonstrate that the TR and prothrombin mRNAs are expressed by distinct but overlapping populations of cells in several brain areas. The results confirm the findings of Niclou et al. (1994), and extend them to demonstrate a much broader CNS distribution and heterogeneous cellular localization for TR mRNA than previously reported. The findings suggest a number of possible roles for the thrombin/TR cell signaling system in neural development, physiology, and pathophysiology.

\section{Cellular localization of TR $m R N A$}

The most striking feature of the cellular localization of TR mRNA was the broad diversity of cellular labeling, which included both neurons and non-neural cells. The pattern of neuronal labeling with the TR cRNA indicates that the receptor is expressed by a large number of neurochemically and functionally distinct cell types. In brainstem, high levels of TR cRNA hybridization occurred in neurons in all three monoaminergic systems, in motor (i.e., cholinergic) and sensory cranial nerve nuclei, and in numerous relay nuclei in the pretectum and accessory optic system. In the telencephalon, the distribution of labeling indicates expression by GABAergic granule cells of the olfactory bulb (Ribak et al., 1977), glutamatergic projection neurons of the anterior thalamus (Kaneko and Mizuno, 1988), as well as probable glutamatergic neurons in superficial olfactory cortex (Walker and Fonnum, 1983), to name a few. The specific neuronal type or types that express very high levels of TR mRNA in cortex cannot be determined from the present results alone, although the broad laminar distribution suggests they are intrinsically projecting cells. Nevertheless, the diversity of neuronal TR cRNA hybridization implies that thrombin, via this receptor, might induce broadly distributed, but sharply cell-specific, morphological and physiological effects on neurons, as previously demonstrated in vitro (Hawkins and Seeds, 1986; Gurwitz and Cunningham, 1988; Grand et al., 1989; Jalink and Moolenaar, 1992).

In addition to neuronal expression, the presence of TR mRNA in glia was suggested by the diffuse but low density hybridization distributed across much of forebrain (e.g., caudate/putamen, neocortex) and was directly demonstrated by the colocalization of GFAP immunoreactivity and TR cRNA hybridization in hippocampal astroglia. This finding is consistent with the results of previous in vitro studies demonstrating the ability of thrombin and TR-activating peptides to regulate morphologic plasticity (Cavanaugh et al., 1990; Nelson and Simon, 1990) and induce mitogenesis (Cavanaugh ct al,, 1990; Grabham and Cunningham, in press) in astrocytes. As discussed above, glial labeling was distributed unevenly across CNS structures and there was considerable variation in TR mRNA expression among different glial cell subtypes. Thus, although GFAP-positive protoplasmic astrocytes in the hippocampal molecular layers express relatively high levels of TR mRNA, astroglial cells prevalent in layer I of neo- and allocortex were not similarly labeled. Moreover, myelinated fiber tracts such as the corpus callosum and anterior commissure, that are enriched in oligodendroglia and fibrous astrocytes, were uniformly TR mRNA negative. The heterogeneity in TR mRNA expression among glial cell subtypes could reflect differing functional requirements for thrombin responsiveness. It should be noted that localization of TR mRNA in astroglia differs with the findings of a recent study (Niclou et al., 1994) that reported no readily detectable astrocytic expres- sion of TR mRNA in P28 rat brain. The discrepancy with our results may reflect differences in the sensitivity of in situ hybridization techniques.

TR mRNA expression was observed in the ependymal cells of the choroid plexus and ventricular lining, indicating that these cells are potential targets for thrombin action, and that the thrombin/TR cell signaling system could influence the secretion and/or uptake of cerebrospinal fluid (CSF) as well as the transport of substances to and from the underlying neuropil. Detection of thrombin in normal adult human CSF has been reported (Beecher et al., 1994), implying that the protease has direct contact with ependymal cells. Proposed mechanisms for CSF secretion suggest that ependymal cells generate osmotic gradients through active transport of ions across their apical surface (Wright, 1972). Furthermore, there is evidence to suggest that CSF-borne protein can be transported across the choroid epithelia by adsorptive endocytosis (Balin and Broadwell, 1988). Thrombin can activate $\mathrm{Na}^{+} / \mathrm{H}^{+}$ion exchangers (Lowe et al., 1990; Sardet et al., 1991), and can induce endosomal vacuole formation (Brass et al., 1994) in a variety of cell types. It is possible that similar thrombin-induced cellular events occur in ependymal cells, influencing the flow of CSF, ions, and metabolites.

In contrast to ependymal cells, cerebrovascular endothelial cells were generally negative for TR cRNA hybridization in the P25 rat brain sections used in our study. A previous study has identified TR mRNA in embryonic mouse brain capillary endothelial cells (Soifer et al., 1994). Together, these findings imply that TR mRNA expression in these cells might be downregulated during development. Thrombin is known to alter the permeability of cultured endothelial cells to ions (Garcia et al., 1993) and proteins (DeMichele et al., 1990). It is possible that small amounts of thrombin generated at the luminal surface of cerebrovascular endothelial cells could activate TR and induce similar responses in vivo. Since formation of the blood-brain barrier in rat occurs gradually during embryogenesis and complete closure to macromolecules is not achieved until the third postnatal week (Risau and Wolburg, 1990), developmental regulation of TR gene expression could provide a cell-specific mechanism for modulating cerebrovascular permeability.

\section{Codistribution of TR and prothrombin mRNAs}

The distributions of TR and prothrombin mRNAs were evaluated and compared in hippocampus, cerebellum, and olfactory bulb, all laminated structures where it is possible to attribute patterns of hybridization to specific cellular populations. The distribution of labeling in each area demonstrated overlapping but distinct patterns of cellular localization, with TR mRNA expression being the more focal and intense but also more heterogeneous as to cell type. For example, in hippocampus, TR cRNA hybridization was densest in neurons lining the hilar side of stratum granulosum and in astroglia of the molecular layers with lower density hybridization in stratum pyramidale. Prothrombin cRNA hybridization labeled the full granule and pyramidal cells layers with moderate density, but did not label glial cells. In cerebellum, TR mRNA was localized to the Purkinje cell layer, whereas prothrombin mRNA was localized to both the Purkinje and granule cell layers. It is intriguing that in each structure examined, the fields of TR/prothrombin mRNA codistribution corresponded with late developing regions containing neurons actively engaged in processes such as differentiation, growth, and synaptic remodeling. In hippocampus, cells within the hilar 
side of stratum granulosum continue to proliferate into the adult period and give rise to both granule cells and glial cells (Bayer, 1980; Cameron et al., 1993). In cerebellum, the innervation of the Purkinje cells remains dynamic through the first 4 postnatal weeks, with ongoing dendritic elaboration and both formation and elimination of synaptic connections (Altman, 1972). However, it should be noted that the distribution of TR cRNA hybridization in the Purkinje cell layer could be associated with either the principal neurons or with the Bergmann glial cell bodies that are also found in this lamina (Voogd, 1985). Nevertheless, the codistribution of prothrombin with TR mRNA in each of these cell layers suggests that locally synthesized thrombin could be acting in an autocrine or paracrine manner to regulate specific developmental processes.

The pattern of prothrombin and TR mRNA codistribution in the olfactory bulb suggests the possible involvement of thrombin and the TR in the establishment of afferent innervation. During both postnatal development and in adulthood, there is continual ingrowth of sensory axons within the olfactory nerve layer, and formation of new synapses on mitral cell dendrites (Brunjes and Frazier, 1986). In the present study, prothrombin cRNA labeled all neuronal layers in the olfactory bulb, while TR gene expression occurred primarily in the mitral and granule cell layers. Furthermore, previous work has identified high levels of PN-1 in the olfactory nerve layer (Reinhard et al., 1988). These expression patterns, taken together with thrombin's ability to repulse growth cone extension (Hawkins and Seeds, 1989) in vitro, suggest that sensory axons may require blockage of thrombin activity by $\mathrm{PN}-1$ as they grow through the nerve and into the olfactory bulb. Once within that target, locally synthesized thrombin, in the absence of its specific inhibitor, could influence formation of synapses between TR-bearing mitral cell dendrites and sensory axon terminals. This hypothesis would predict that TR protein should be expressed on the extended dendritic processes of mitral cells. Future immunohistochemical studies are needed to examine this possibility.

\section{TR MRNA expression in areas vulnerable to neuronal damage}

In light of recent findings indicating that thrombin can regulate the viability of neural cells in culture (P. J. Vaughan, C. J. Pike, C. W. Cotman, and D. D. Cunningham, unpublished observations), it is intriguing that high levels of TR mRNA expression occurred in several regions containing vulnerable neuronal populations. In the present study, the dopaminergic neurons of the substantia nigra/ventral tegmental area provided the most striking example of a known pathophysiologic target cell population genterating intense TR cRNA hybridization. Selective degeneration of the mesostriatal dopaminergic neurons results in the motor disorders of Parkinson's disease (Javoy-Agid et al., 1984). A previous study has reported that dopaminergic neurons from human fetal midbrain cultures retract their processes upon exposure to thrombin (Detta et al., 1992) and are, thus, likely to express functional TR. In addition, a very recent study reported de novo astroglial synthesis of $\mathrm{PN}-1$ in the substantia nigra following excitotoxic chemical insult (Scotti et al., 1994). Thrombin can elicit changes in the levels of intracellular second messengers (e.g., cAMP and calcium) similar to those induced by neuronal excitotoxins like glutamate (Nakanishi, 1992). One intriguing possibility is that the increase in $\mathrm{PN}-1$ synthesis represents a protective response designed to limit TR activation on susceptible dopaminergic cells, and that this response is impaired in certain disease states. However, even if the PN-1 re- sponse remains intact, the high levels of TR mRN $\Lambda$ expression by dopaminergic neurons reveal a potentially important target cell population for thrombin's putative neuroprotective and/or neurotoxic actions.

TR cRNA hybridization was observed in a second vulnerable population, the hippocampal pyramidal cell neurons, known to selectively degenerate following ischemia (Kirino, 1982; Meldrum and Garthwaite, 1990). Previous work has demonstrated thrombin induces neurite retraction in cultured hippocampal pyramidal neurons (Farmer et al., 1990). The in vivo expression of TR mRNA in these cells identifies them as another potential target for the possible deleterious effects of excess thrombin exposure. Ischemia induces significant and long-lasting increases in the level of PN-1 immunoreactivity associated with astrocytes in hippocampal CA fields (Hoffmann et al., 1992). Since TR cRNA clearly labeled GFAP-positive astrocytes in these same molecular layers, tight control of thrombin's proteolytic activity might be an important element in the hippocampal response to ischemic insult. The astrocytic localization of TR mRNA in the hippocampus is particularly interesting in light of a recent study demonstrating a TR mediated enhancement of nerve growth factor synthesis and secretion by primary cultures of glial cells (Neveu et al., 1993). Hippocampal astrocytes could represent a thrombin responsive cell population with the capacity to synthesize $\mathrm{PN}-1$ or other protective factors following ischemia and concomitant exposure to extravasated thrombin.

\section{References}

Altman J (1972) Postnatal development of the cerebellar cortex in the rat. II. Phases in the maturation of Purkinje cells and of the molecular layer. J Comp Neurol 145:399-463.

Baker JB, Low DA, Simmer RL, Cunningham DD (1980) Proteasenexin: a cellular component that links thrombin and plasminogen activator and mediates their binding to cells. Cell 21:37-45.

Balin BJ, Broadwell RD (1988) Transcytosis of protein through the mammalian cerebral epithelium and endothelium. I. Choroid plexus and the blood-cerebrospinal fluid barrier. J Neurocytol 17:809-826.

Bar-Shavit R, Kahn A, Fenton JW II, Wilner GD (1983) Receptormediated chemotactic response of a macrophage cell line (J774) to thrombin. Lab Invest 49:702-707.

Bayer SA (1980) Development of the hippocampal region in the rat. II. Morphogenesis during embryonic and early postnatal life. J Comp Neurol 190:115-134.

Beecher KL, Andersen TT, Fenton II JW, Festoff BW (1994) Thrombin receptor peptides induce shape change in neonatal murine astrocytes in culture. J Neurosci Res 37:108-115.

Berndt M, Phillips D (1981) Platelet membrane proteins: composition and receptor function. In: Platelets in biology and pathology (Gordon J, ed), pp 43-74. Amsterdam: Elsevier/North Holland.

Brass LF, Pizarro S, Ahuja M, Belmonte E, Blanchard N, Stadel JM, Hoxie JA (1994) Changes in the structure and function of the human thrombin receptor during receptor activation, internalization, and recycling. J Biol Chem 269:2943-2952.

Brunjes PC, Frazier LL (1986) Maturation and plasticity in the olfactory system of vertebrates. Brain Res 396:1-45.

Cameron HA, Woolley CS, McEwen BS, Gould E (1993) Differentiation of newly born neurons and glia in the dentate gyrus of the adult rat. Neuroscience 56:337-344.

Cavanaugh K, Gurwitz D, Cunningham DD, Bradshaw R (1990) Reciprocal modulation of astrocyte stellation by thrombin and Protease Nexin-1. J Neurochem 54:1735-1743.

Chen J, Ishii M, Wang L, Ishii K, Coughlin SR (1994) Thrombin receptor activation: confirmation of the intramolecular tethered liganding hypothesis and discovery of an alternative intermolecular liganding mode. J Biol Chem 269:16041-16045.

Choi BH, Suzuki M, Kim T, Wagner SL, Cunningham DD (1990) Protease nexin-1: localization in the human brain suggests a protective role against extravasated serine proteases. Am J Pathol 137:741-747.

Chomczynski P, Sacchi N (1987) Single-step method of RNA isolation 
by acid guanidinium thiocyanate-phenol-chloroform extraction. Anal Biochem 162:156-159.

Chuong CM (1990) Differential roles of multiple adhesion molecules in cell migration: granule cell migration in cerebellum. Experientia 46:892-899.

Daniel TO, Gibbs VC, Milfay DF, Garovoy MR, Williams LT (1986) Thrombin stimulates c-sis gene expression in microvascular endothelial cells. J Biol Chem 261:9579-9582.

DeMichele MA, Moon DG, Fenton II JW, Minnear FL (1990) Thrombin's enzymatic activity increases permeability of endothelial cell monolayers. J Appl Physiol 69:1599-1606.

Deschepper CF, Bigornia V, Berens ME, Lapointe MC (1991) Production of thrombin and antithrombin III by brain and astroglial cell cultures. Brain Res Mol Brain Res 11:355-358.

Detta A, Grabham P, Hitchcock E (1992) Phenotypic plasticity of 'mature' human mesencephalic dopaminergic neurons and glial cells. Restorat Neurol Neurosci 4:41-46.

Dihanich M, Kaser M, Reinhard E, Cunningham D, Monard D (1991) Prothrombin mRNA is expressed by cells of the nervous system. Neuron 6:575-581.

Ehrenreich H, Costa I, Clouse KA, Pluta RM, Ogino Y, Coligan JE, Burd PR (1993) Thrombin is a regulator of astrocytic endothelin-1. Brain Res 600:201-207.

Farmer L, Sommer J, Monard D (1990) Glial-derived nexin potentiates neurite extension in hippocampal pyramidal cells in vitro. Dev Neurosci $12: 73-80$

Garcia JG, Patterson C, Bahler C, Aschner J, Hart CM, English D (1993) Thrombin receptor activating peptides induce $\mathrm{Ca}^{2+}$ mobilization, barrier dysfunction, prostaglandin synthesis, and platelet-derived growth factor mRNA expression in cultured endothelium. J Cell Physiol 156:541-549.

Gerszten RE, Chen J, Ishii M, Ishii K, Wang L, Nanevicz T, Turck CW, Vu TK, Coughlin SR (1994) Specificity of the thrombin receptor for agonist peptide is defined by its extracellular surface. Nature 368 : 648-651.

Glenn KC, Carney DH, Fenton JW, Cunningham DD (1980) Thrombin active site regions required for fibroblast receptor binding and initiation of cell division. J Biol Chem 255:6609-6616.

Grabham PW, Cunningham DD (in press) Thrombin receptor activation stimulates astrocyte proliferation and reversal of stellation by distinct pathways: involvement of tyrosine phosphorylation. $\mathbf{J}$ Neurochem, in press

Grand RJ, Grabham PW, Gallimore MJ, Gallimore PH (1989) Modulation of morphological differentiation of human neuroepithelial cells by serine proteases: independence from blood coagulation. EMBO J $8: 2209-2215$

Gurwitz D, Cunningham DD (1988) Thrombin modulates and reverses neuroblastoma neurite outgrowth. Proc Natl Acad Sci USA 85:34403444.

Gurwitz D, Cunningham DD (1990) Neurite outgrowth activity of protease nexin-1 on neuroblastona cells requires thrombin inhibition. J Cell Physiol 142:155-162.

Hawkins RL, Seeds NW (1986) Effect of proteases and their inhibitors on neurite outgrowth from neonatal mouse sensory ganglia in culture. Brain Res 398:63-70.

Hawkins RL, Seeds NW (1989) Protease inhibitors influence the direction of neurite outgrowth. Brain Res 45:203-209.

Hoffmann MC, Nitsch C, Scotti AL, Reinhard E, Monard D (1992) The prolonged presence of glia-derived nexin, an endogenous protease inhibitor, in the hippocampus after ischemia-induced delayed neuronal death. Neuroscience 49:397-408.

Hung DT, Wong YH, Vu TK, Coughlin SR (1992) The cloned platelet thrombin receptor couples to at least two distinct effectors to stimulate phosphoinositide hydrolysis and inhibit adenylyl cyclase. J Biol Chem 267:20831-20834.

Jalink K, Moolenaar WH (1992) Thrombin receptor activation causes rapid neural cell rounding and neurite retraction independent of classic second messengers. J Cell Biol 118:411-419.

Javoy-Agid F, Ruberg M, Taquet H, Bokobza B, Agid Y, Gaspar P, Berger B, N'Guyen-Legros J, Alvarez C, Gray F (1984) Biochcmical neuropathology of Parkinson's disease. Adv Neurol 40:189-198.

Kaneko T, Mizuno N (1988) Immunohistochemical study of glutaminase-containing neurons in the cerebral cortex and thalamus of the rat. J Comp Neurol 267:590-602:
Kirino T (1982) Delayed neuronal death in the gerbil hippocampus following ischemia. Brain Res 239:57-69.

Koo EH, Abraham CR, Potter H, Cork LC, Price DL (1991) Developmental expression of alpha 1-antichymotrypsin in brain may be related to astrogliosis. Neurobiol Aging 12:495-501.

Lauterborn JC, Isackson PJ, Gall CM (1991) Nerve growth factor mRNA-containing cells are distributed within regions of cholinergic neurons in the rat basal forebrain. J Comp Neurol 306:439-446.

Liotta LA, Goldfarb RH, Brundage R, Siegal GP, Terranova V, Garbisa S (1981) Efrect of plasminogen activator (urokinase), plasmint, and thrombin on glycoprotein and collagenous components of basement membrane. Cancer Res 41:4629-4636.

Liu Y, Fields RD, Fitzgerald S, Festoff BW, Nelson PG (1994) Proteolytic activity, synapse elimination, and the Hebb synapse. J Neurobiol 25:325-335.

Lowe JH, Huang CL, Ives HE (1990) Sphingosine differentially inhibits activation of the $\mathrm{Na}^{+} / \mathrm{H}^{+}$exchanger by phorbol esters and growth factors. J Biol Chem 265:7188-7194.

Meldrum B, Garthwaite J (1990) Excitatory amino acid neurotoxicity and neurodegenerative disease. Trends Pharmacol Sci 11:379-387.

Monard D (1988) Cell-derived proteases and protease inhibitors as regulators of neurite outgrowth. Trends Neurosci 11:541-544.

Nakanishi S (1992) Molecular diversity of glutamate receptors and implications for brain function. Science 258:597-603.

Nelson RB, Simon R (1990) Thrombin and its inhibitors regulate morphological and biochemical differentiation of astrocytes in vitro. Brain Res Dev Brain Res 54:93-104.

Neveu I, Jehan F, Jandrot-Perrus M, Wion D, Brachet P (1993) Enhancement of the synthesis and secretion of nerve growth factor in primary cultures of glial cells by proteases: a possible involvement of thrombin. J Neurochem 60:858-867.

Niclou S, Suidan H, Brown-Luedi M, Monard D (1994) Expression of the thrombin receptor mRNA in rat brain. Cell Mol Biol 40:421-428.

Nishino A, Suzuki M, Ohtani H, Motohashi O, Umezawa K, Nagura H, Yoshimoto T (1993) Thrombin may contribute to the pathophysiology of central nervous injury. J Neurotrauma 10:167-179.

Pittman RN, Ivins JK, Buettner HM (1989) Neuronal plasminogen activators: cell surface binding sites and involvement in neurite outgrowth. J Neurosci 9:4269-4286.

Rasmussen UB, Vouret-Craviari V, Jallat S, Schlesinger Y, Pages G, Pavirani A, Lecocq JP, Pouyssegur J, Van Obberghen-Schilling E (1991) cDNA cloning and expression of a hamster alpha-thrombin receptor coupled to $\mathrm{Ca}^{2+}$ mobilization. FEBS Lett 288:123-128.

Reinhard E, Meier R, Halfter W, Rovelli G, Monard D (1988) Detection of glia-derived nexin in the olfactory system of the rat. Neuron 1:387-394.

Reinhard E, Suidan H, Pavlik A, Monard D (1994) Glia-derived nexin/ protease nexin- 1 is expressed by a subset of neurons in the rat brain. J Neurosci Kes 3\%:256-2\%.

Ribak CE, Vaughn JE, Saito K, Barber R, Roberts E (1977) Glutamate decarboxylase localization in neurons of the olfactory bulb. Brain Res 126:1-18.

Risau W, Wolburg H (1990) Development of the blood-brain barrier. Trends Neurosci 13:174-178.

Sardet C, Fafournoux P, Pouyssegur J (1991) Alpha-thrombin, epidermal growth factor, and okadaic acid activate the $\mathrm{Na}^{+} / \mathrm{H}^{+}$exchanger, NHE-1, by phosphorylating a set of common sites. J Biol Chem 266: 19166-19171.

Scott RW, Bergman BL, Bajpai A, Hersh RT, Rodriguez H, Jones BN, Barreda C, Watts S, Baker JB (1985) Protease nexin: properties and a modified purification procedure. J Biol Chem 260:7029-7034.

Scotti AL, Monard D, Nitsch C (1994) Re-expression of glia-derived nexin/protease nexin 1 depends on mode of lesion-induction or terminal degeneration: observations after excitotoxin or 6-hydroxydopamine lesions of rat substantia nigra. J Neurosci Res 37:155-168.

Seeds N, Verrall S, McGuire P, Friedmann G, Leprince P, Rogister B, Delree P, Lefebvre P, Rigo J, Moonen G, Pittman R, Repka A, Ware J, LaRosa A, Kalderon N (1990) Serine proteases in the nervous system. In: Serine proteases and their serpin inhibitors in the nervous system: regulation in development and in degenerative and malignant disease (Festorf B, ed), pp 173-216. New York: Plenum.

Soifer SJ, Peters KG, O'Keefe J, Coughlin SR (1994) Disparate temporal expression of the prothrombin and thrombin receptor genes during mouse development. Am J Pathol 144:60-69.

Suidan HS, Stone SR, Hemmings BA, Monard D (1992) Thrombin 
causes neurite retraction in neuronal cells through activation of cell surface receptors. Neuron 8:363-375.

Sumi Y, Dent MA, Owen DE, Seeley PJ, Morris RJ (1992) The expression of tissue and urokinase-type plasminogen activators in neural development suggests different modes of proteolytic involvement in neuronal growth. Development 116:625-637.

Trejo J, Chambard JC, Karin M, Brown JH (1992) Biphasic increase in c-jun mRNA is required for induction of AP-1-mediated gene transcription: differential effects of muscarinic and thrombin receptor activation. Mol Cell Biol 12:4742-4750.

Voogd J, Gerritts NM, Marani E (1985) Cerebellum. In: The rat nervous system, Vol 2, hindbrain and spinal cord (Paxinos G, ed), pp 251-291. London: Academic.

Vu TK, Hung DT, Wheaton VI, Coughlin SR (1991a) Molecular cloning of a functional thrombin receptor reveals a novel proteolytic mechanism of receptor activation. Cell 64:1057-1068.
Vu TK, Wheaton VI, Hung DT, Charo I, Coughlin SR (1991b) Domains specifying thrombin-receptor interaction. Nature 353:674-677.

Wagner SL, Van Nostrand WE, Lau AL, Farrow JS, Suzuki M, Bartus RT, Schuppek R, Nguyen A, Cotman CW, Cunningham DD (1993) Co-distribution of protease nexin- 1 and protease nexin- 2 in brains of non-human primates. Brain Res 626:90-98.

Walker JE, Fonnum F (1983) Regional cortical glutamergic and aspartergic projections to the amygdala and thalamus of the rat. Brain Res 267:371-374.

Wright EM (1972) Mechanisms of ion transport across the choroid plexus. J Physiol (Lond) 226:545-571.

Zhong C, Hayzer DJ, Corson MA, Runge MS (1992) Molecular cloning of the rat vascular smooth muscle thrombin receptor. Evidence for in vitro regulation by basic fibroblast growth factor. J Biol Chem 267:16975-16979. 